Foot and mouth
Effective vaccine
treatment for animal
virus remains elusive
$p 4$

\title{
Bush declines to support drug companies' line on AIDS profits
}

\section{David Dickson}

The administration of president George W. Bush has surprised international aid organizations and AIDS activists by indicating that it will take a liberal attitude towards developing countries' efforts to produce generic versions of expensive drugs.

The move coincides with a heated public controversy over the situation faced by sufferers of diseases such as AIDS, who are unable to afford even discounted prices.

Next week, for example, a South African court will hear a challenge by 42 pharmaceutical companies against the government for allowing the domestic production of cheaper versions of their anti-AIDS drugs.

Meanwhile Father Angelo d'Agostino, head of Nyumbani Orphanage for children with HIV or AIDS in the Kenyan capital Nairobi, said last Friday that he plans to accept an offer by the Indian company Cipla of Mumbai, which has promised to make the drugs available at about one-third of the minimum cost on offer from the Western companies (see Nature 409, 751; 2001).

The previous US administration decided in 1999 to take a more relaxed attitude to developing countries wishing to produce their own versions of expensive anti-AIDS drugs patented in the West. Bush had been widely expected to reverse this decision .

But last week, Robert Zoellick, the US trade representative, said that the United States was not planning to change the current policy. He promised to back efforts by the administration "to work with countries that develop serious programmes to prevent and treat this horrible disease", provided such efforts were "consistent with our overall efforts to protect America's investment in intellectual property".

The statement's significance was played down by the Pharmaceutical Research and Manufacturers of America, which has been pressing for the United States to take action against countries such as Brazil which it claims are undermining US patent interests by producing generic drugs.

But it was warmly welcomed by AIDS activists and public-interest groups. They are hoping that the embarrassment being

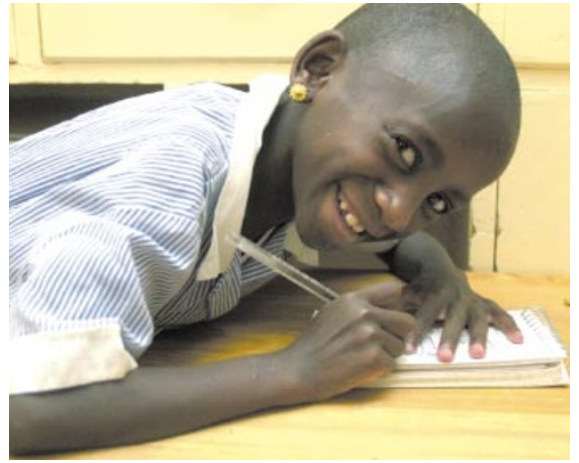

Hopeful sign: Christine Gatwiri, 7, at Nyumbani.

caused to major drug companies such as Boehringer Ingelheim and GlaxoSmithKline will persuade them to modify their stance.

Some are saying the publicly funded laboratories which carried out research leading to the development of these drugs should also become involved. James Love, director of the Washington-based Consumer Project on Technology, says US institutions that own patents on important HIV drugs should endorse Cipla's request for a licence to sell its

\section{Growers cotton on to GM bollworm}

\section{Rex Dalton, San Diego}

The first US field test of a genetically modified insect is being planned in Arizona. Organizers say its outcome could help control the pink bollworm, a cotton pest.

Researchers from the US Department of Agriculture (USDA) and the University of California (UC) at Riverside will issue a public notice in a few weeks, kicking off the process needed to obtain permission for the test.

About 3,600 moths, which produce the bollworm larvae that burrow into cotton, will be studied in a one-hectare enclosure in a field near Phoenix. They will have been modified with a genetic marker - enhanced green fluorescent protein, from a jellyfish so that they can be tracked.

Later, the team plans to introduce a 'lethal gene' designed to kill the progeny of drugs in developing countries where the Western patents are valid, paying the patentholders royalties of up to $5 \%$.

"Where licences cannot be obtained voluntarily [for the domestic production of generic anti-AIDS drugs], it is now time for the World Health Organization, UNAIDS, the World Bank, governments or non-governmental organizations to obtain compulsory licences," he adds. "It is morally repugnant to delay this process any longer."

But others are arguing that the situation should be addressed by increasing the amount of money available through aid programmes to purchase anti-AIDs drugs.

Meanwhile the aid agency Médicins san Frontières (MSF) has agreed to distribute Cipla's three-drug antiretroviral cocktail free of charge in 10 countries. "Wherever it is purchased by governments, it would be sold at reduced prices," Daniel Berman of MSF said last week. He said the agency would integrate some Cipla drugs into antiretroviral pilot programmes in 10 countries including Thailand and Cameroon, where the programme has already started.

both engineered and naturally occurring moths. Testing of moths with the lethal gene will require an additional review period and permit, federal officials say.

The method was developed by a team headed by UC Riverside entomologist Thomas Miller and USDA entomologist Robert Staten in Phoenix, with a \$1 million grant from cotton growers. They say that the moths are an invasive species that plays no role in the local ecosystem.

But Charles Margulis, who monitors genetic issues for Greenpeace, calls the tests "a clear and present danger of irreversible damage".

John Caravetta, of the Arizona Agriculture Department, which has veto power, said the state supports the concept, but needs to see the final plan before commenting in detail. 